
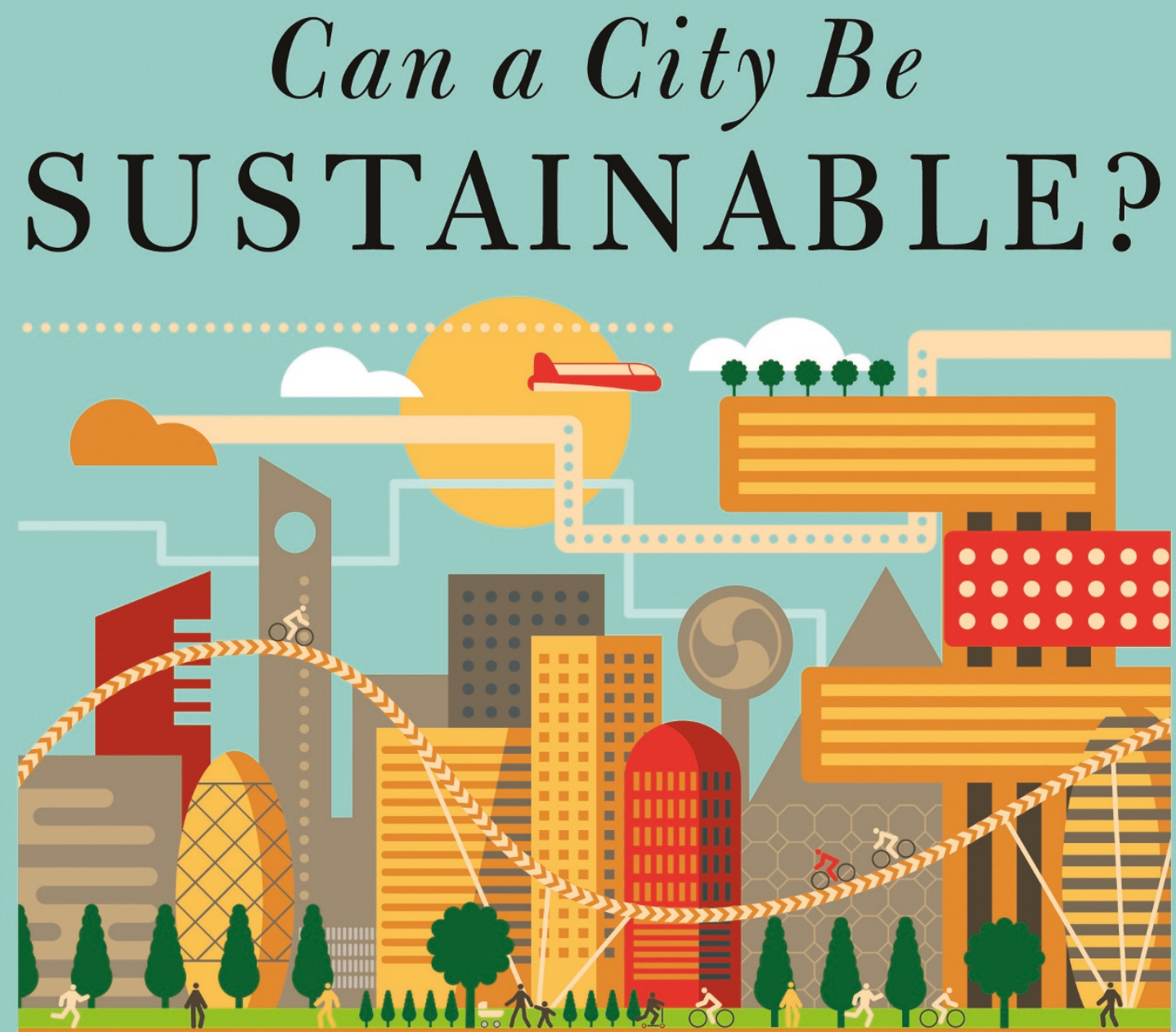

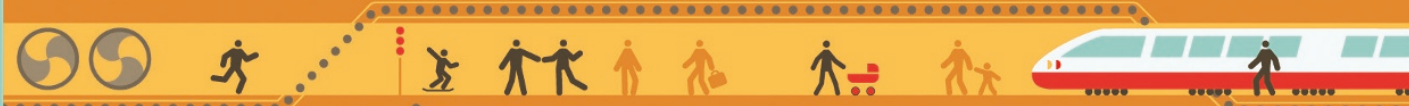

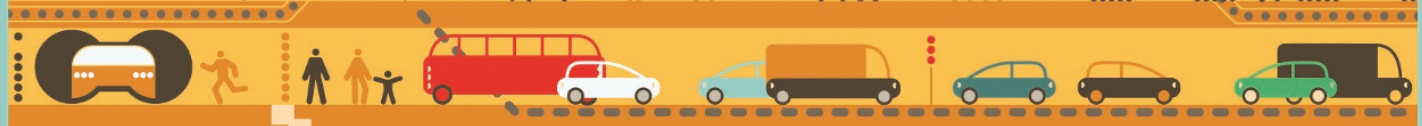

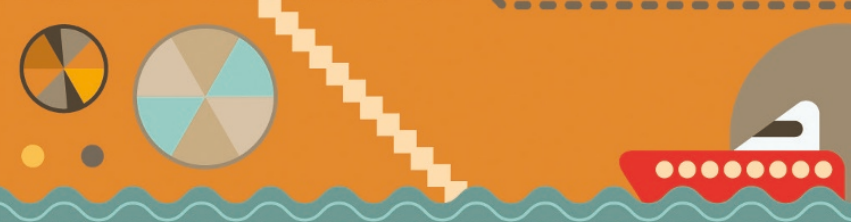

Non

THE WORLDWATCH INSTITUTE 



\section{STATE OF THE WORLD}

Can a City Be

Sustainable? 


\section{Other Worldwatch Books}

State of the World 1984 through 2015

(an annual report on progress toward a sustainable society)

Vital Signs 1992 through 2003 and 2005 through 2015

(a report on the trends that are shaping our future)

Saving the Planet

Lester R. Brown

Christopher Flavin

Sandra Postel

How Much Is Enough?

Alan Thein Durning

Last Oasis

Sandra Postel

Full House

Lester R. Brown

Hal Kane
Power Surge

Christopher Flavin

Nicholas Lenssen

Who Will Feed China?

Lester R. Brown

Tough Choices

Lester R. Brown

Fighting for Survival

Michael Renner

The Natural Wealth of Nations

David Malin Roodman

Life Out of Bounds

Chris Bright
Beyond Malthus

Lester R. Brown

Gary Gardner

Brian Halweil

Pillar of Sand

Sandra Postel

Vanishing Borders

Hilary French

Eat Here

Brian Halweil

Inspiring Progress

Gary Gardner 


\section{STATE OF THE WORLD}

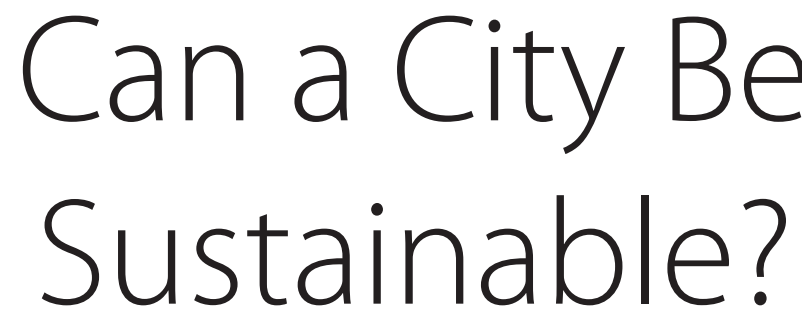

Gary Gardner, Tom Prugh, and Michael Renner, Project Directors

Betsy Agar

Perinaz Bhada-Tata

Peter Calthorpe

Alexander Carius

Andrew Cumbers

Geoffrey Davison

Robert Doyle

Richard Friend

Sudhir Gota

Pablo Knobel Guelar

Richard Heinberg
Brian Holland

Daniel Hoornweg

Cornie Huizenga

Jim Jarvie

Madhavi Joshi

Martí Boada Juncà

Gregory H. Kats

Anna Larsson

Haibing Ma

Sanskriti Menon

Sean O'Donoghue

Lisa Mastny, Editor
Karl Peet

Simone Ariane Pflaum

Ang Wei Ping

Debra Roberts

Gregor Robertson

Kartikeya Sarabhai

Franziska Schreiber

Kristina Solheim

Juan Wei

Peter Wrenfelt

Roser Maneja Zaragoza

\section{ISLANDPRESS}

Washington | Covelo | London 
Copyright (c) 2016 by Worldwatch Institute 1400 16th Street, NW

Suite 430

Washington, DC 20036

www.worldwatch.org

The State of the World and Worldwatch Institute trademarks are registered in the U.S. Patent and Trademark Office.

The views expressed are those of the authors and do not necessarily represent those of the Worldwatch Institute; of its directors, officers, or staff; or of its funders.

All rights reserved under International and Pan-American Copyright Conventions. No part of this book may be reproduced in any form or by any means without permission in writing from the publisher: Island Press, 2000 M Street, NW, Suite 650, Washington, DC 20036.

Island Press is a trademark of Island Press/The Center for Resource Economics.

Library of Congress Control Number: 2016933396

ISBN 13: 978-1-61091-755-1

ISBN 10: 1-61091-755-3

The text of this book is composed in Minion Pro, with the display set in Myriad Pro. Book design and composition by Lyle Rosbotham.

Printed on recycled, acid-free paper

Manufactured in the United States of America 
For additional related and updated content, videos, infographics, data, blog posts, and links, visit www.canacitybesustainable.org.

\section{Worldwatch Institute Board of Directors}

Ed Groark

Chair and Acting President

UNITED STATES

Robert Charles Friese

Vice Chair

UNITED STATES

John Robbins

Treasurer

UNITED STATES

Mike Biddle

UNITED STATES
Tom Crain

UNITED STATES

James Dehlsen

UNITED STATES

Edith Eddy

UNITED STATES

Ping $\mathrm{He}$

UNITED STATES

Stefan Mueller

UNITED STATES
David W. Orr

UNITED STATES

Scott Schotter

UNITED STATES

Richard Swanson

UNITED STATES

Emeritus:

Øystein Dahle NORWAY

Abderrahman Khene ALGERIA 


\section{Worldwatch Institute Staff}

$\begin{array}{lll}\text { Ed Groark } & \text { Philip Killeen } & \text { Mary C. Redfern } \\ \text { Acting President } & \text { Research Associate, Climate and } & \begin{array}{l}\text { Director of Institutional } \\ \text { Relations, Development }\end{array} \\ \text { Kevin De Cuba } & \text { Energy Program } & \text { Michael Renner } \\ \text { Caribbean Program Manager } & \text { Haibing Ma } & \text { Senior Researcher } \\ \text { Barbara Fallin } & \text { China Program Manager } & \text { Wanqing Zhou } \\ \text { Director of Finance and } & \text { Lisa Mastny } & \text { Research Associate, Food and } \\ \text { Administration } & \text { Senior Editor } & \text { Agriculture Program } \\ \text { Gary Gardner } & \text { Alexander Ochs } & \\ \text { Director of Publications } & \text { Director, Climate and Energy } \\ \text { Gaelle Gourmelon } & \text { Program } & \\ \text { Marketing and Communications } & \text { Tom Prugh } & \\ \text { Director } & \text { Senior Researcher } & \end{array}$

\section{Worldwatch Institute Fellows, Advisers, and Consultants}

Erik Assadourian

Senior Fellow

Jorge Barrigh

Senior Fellow

Maria Gabriela da Rocha Oliveira

Senior Fellow

Julian Despradel

Senior Fellow
Robert Engelman

President Emeritus/Senior Fellow

Mark Konold

Senior Fellow

Corey Perkins

Information Technology Manager
Lyle Rosbotham Art and Design Consultant

Preeti Shroff-Mehta

Senior Fellow

Anmol Vanamali

Senior Fellow 


\section{Contents}

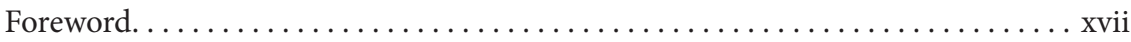

Garrett Fitzgerald

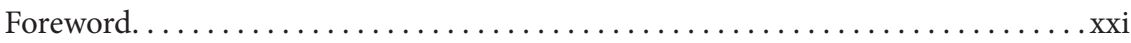
Eduardo da Costa Paes

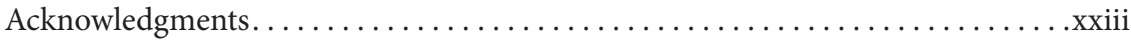

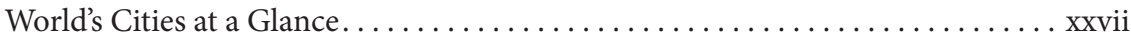
Gary Gardner

\section{CITIES AS HUMAN CONSTRUCTS}

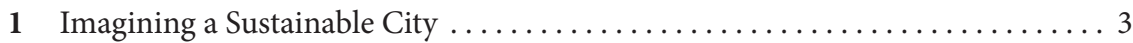
Gary Gardner

2 Cities in the Arc of Human History: A Materials Perspective . . . . . . . . . 11 Gary Gardner

3 The City: A System of Systems . . . . . . . . . . . . . . . 27 Gary Gardner

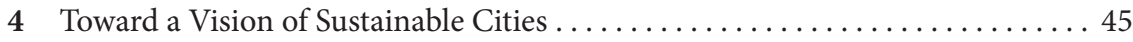
Gary Gardner

5 The Energy Wildcard: Possible Energy Constraints to Further Urbanization. . 65 Richard Heinberg

\section{THE URBAN CLIMATE CHALLENGE}

6 Cities and Greenhouse Gas Emissions: The Scope of the Challenge. . . . . . . 77 Tom Prugh and Michael Renner

7 Urbanism and Global Sprawl ........................... 91 Peter Calthorpe 
CITY VIEW: Shanghai, China

Haibing $M a$

8 Reducing the Environmental Footprint of Buildings Michael Renner

CITY VIEW: Freiburg, Germany

Simone Ariane Pflaum

9 Energy Efficiency in Buildings: A Crisis of Opportunity . Gregory H. Kats

CITY VIEW: Melbourne, Australia ... Robert Doyle

10 Is 100 Percent Renewable Energy in Cities Possible? Betsy Agar and Michael Renner

CITY VIEW: Vancouver, Canada.

Gregor Robertson

11 Supporting Sustainable Transportation. Michael Renner

12 Urban Transport and Climate Change Cornie Huizenga, Karl Peet, and Sudhir Gota

CITY VIEW: Singapore.

Geoffrey Davison and Ang Wei Ping

13 Source Reduction and Recycling of Waste Michael Renner

CITY VIEW: Ahmedabad and Pune, India

Kartikeya Sarabhai, Madhavi Joshi, and Sanskriti Menon

14 Solid Waste and Climate Change... Perinaz Bhada-Tata and Daniel Hoornweg

CITY VIEW: Barcelona, Spain Martí Boada Juncà, Roser Maneja Zaragoza, and Pablo Knobel Guelar

15 Rural-Urban Migration, Lifestyles, and Deforestation ... 263 Tom Prugh 


\section{POLITICS, EQUITY, AND LIVABILITY}

16 Remunicipalization, the Low-Carbon Transition, and Energy Democracy. . . 275 Andrew Cumbers

CITY VIEW: Portland, Oregon, United States. . . . . . . . . . . . . . . . . . 291

Brian Holland and Juan Wei

17 The Vital Role of Biodiversity in Urban Sustainability . . . . . . . . . . . . . 297 Martí Boada Juncà, Roser Maneja Zaragoza, and Pablo Knobel Guelar

CITY VIEW: Jerusalem, Israel . . . . . . . . . . . . . . . . . . 311 Martí Boada Juncà, Roser Maneja Zaragoza, and Pablo Knobel Guelar

18 The Inclusive City: Urban Planning for Diversity and Social Cohesion. . . . . . 317 Franziska Schreiber and Alexander Carius

CITY VIEW: Durban, South Africa. . . . . . . . . . . . . . . . . 337 Debra Roberts and Sean O’Donoghue

19 Urbanization, Inclusion, and Social Justice . . . . . . . . . . . . 343 Jim Jarvie and Richard Friend

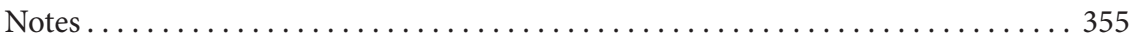

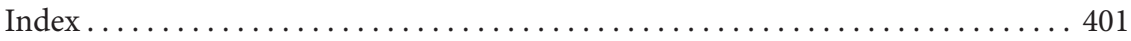





\section{List of Boxes, Tables, and Figures}

BOXES

2-1 Socio-metabolism as an Analytical Tool. .................. 12

2-2 Density: The Law of Human Attraction $\ldots \ldots \ldots \ldots \ldots \ldots \ldots \ldots \ldots \ldots \ldots \ldots \ldots \ldots \ldots \ldots \ldots$

8-1 Green Building Markets and Energy Efficiency Investments. . . . . . . . 121

8-2 Combining Top-down and Bottom-up Policies for Greening Buildings

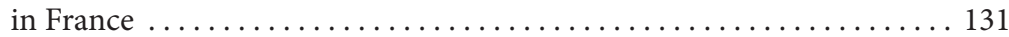

9-1 Supplemental Benefits of Energy Efficiency ................ 153

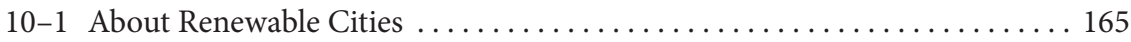

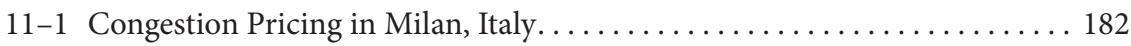

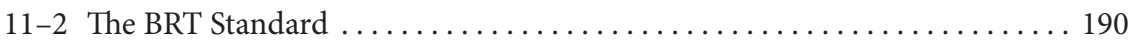

12-1 Best Practices in the Avoid/Shift/Improve Approach . . . . . . . . . . . 208

13-1 What a Waste! Incineration versus Waste Reduction . . . . . . . . . . . . . 224

13-2 Supporting Waste-picker Cooperatives in Brazil. . . . . . . . . . . . . . 227

15-1 Is Urbanization Really a Green Anti-Poverty Strategy? . . . . . . . . . . . . 270

16-1 Hybrid Public Ownership in Buenos Aires Province, Argentina . . . . . . . . 277

16-2 The Pioneering Remunicipalization Town of Wolfshagen, Germany. . . . . . 283

17-1 Let Nature Do the Work, by Anna Larsson and Peter Wrenfelt . . . . . . . . . 299

17-2 The Mediterranean Region: Cradle of Cultures and Biodiversity Hotspot .. 303

18-1 A Review of Four National Urban Planning Programs . . . . . . . . . . 323

18-2 Pro Huerta: Urban Agriculture and Food Security in a Changing World,

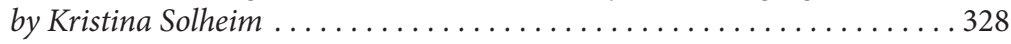

\section{TABLES}

2-1 Metabolic Profiles of Hunter-Gatherers and Agrarian Society . . . . . . . . 16

2-2 Energy Levels Associated with City Size .................. 18 
2-3 Subsistence Regime and Maximum City Size

2-4 Metabolic Profiles of Hunter-Gatherers, Agrarian Society, and Industrial

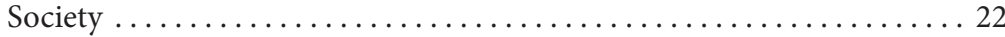

2-5 Relative Contribution of Population, Affluence, and Technology to Environmental Impact Over History . . . . . . . . . . . . . 24

3-1 Urban Direct Final Energy Use by Region, $2005 \ldots \ldots \ldots \ldots \ldots \ldots \ldots \ldots 28$

3-2 Domestic Material Consumption per Person, by Region, 1980 and 2009 . . . 33

3-3 Municipal Solid Waste Generation per Person, Selected Regions, 2005 . . . . 35

3-4 Comparison of Food Parameters in Lusaka, Bogotá, and Manchester. . . . . . 38

3-5 Share of Wastewater Treated, by Country Income Level . . . . . . . . . 42

4-1 Reduced, Circulating, and Clean Flows of Materials: A Checklist for Urban

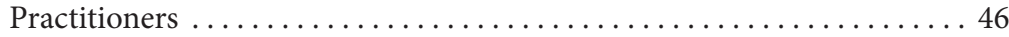

4-2 A Prominent Place for Nature: A Checklist for Urban Practitioners . . . . . . . 49

4-3 Beatley's Indicators for Biophilic City Infrastructure . . . . . . . . . . 52

4-4 Compact and Connected Patterns of Development: A Checklist for Urban

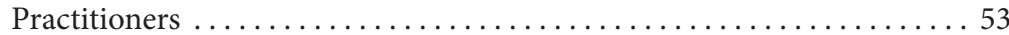

4-5 Creative Placemaking: A Checklist for Urban Practitioners . . . . . . . . . 56

4-6 Cities as Centers of Well-being: A Checklist for Urban Practitioners . . . . . 58

4-7 People-centered Development: A Checklist for Urban Practitioners . . . . . . 61

4-8 Participatory Governance: A Checklist for Urban Practitioners. . . . . . . . 62

6-1 Greenhouse Gas Emission Baselines for Selected Cities and Years. . . . . . . . 78

8-1 Selected Green Building Rating and Certification Systems Worldwide. . . . 119

8-2 Building Construction and Energy Efficiency Investments in the United States, China, and Germany, $2014 \ldots \ldots \ldots \ldots \ldots \ldots \ldots \ldots \ldots \ldots \ldots \ldots$

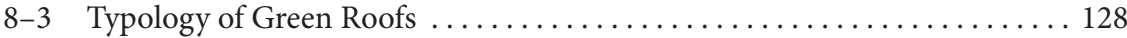

10-1 Community-wide Renewable Energy Targets Set by Selected Local

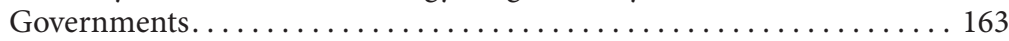

11-1 Characteristics of Light Rail and Metro Systems . . . . . . . . . . 186

11-2 Number and Characteristics of BRT Systems, by Region. . . . . . . . . . 188

12-1 Transport Sector Measures in Selected INDCs . . . . . . . . . . . . 201

13-1 Energy Savings from Recycling versus Virgin Materials Production . . . . . . 219

14-1 Comparison of Solid Waste Management Practices, by Country Income Level . . . . . . . . . . . . . . . . . . . 243 
14-2 Greenhouse Gas Emissions and Savings from the Solid Waste Management System ........................................ 245

14-3 Comparison of Estimated Direct and Avoided Greenhouse Gas Emissions for Waste-to-Energy and Landfilling . ..................... 251

16-1 Examples of Remunicipalization Campaigns in Various Sectors . . . . . . . 278

17-1 Ecosystem Services Provided by Urban Biodiversity . . . . . . . . . . . . . 307

17-2 Motivations and Functions of Urban Biodiversity ............... 309

\section{FIGURES}

2-1 Socio-metabolic Regimes in Human History. ..................... 13

2-2 Urban Share of World Population, 10,000 BCE to 2050 ............ 17

2-3 World's Largest Cities and Their Populations, Selected Years ............ 23

3-1 Share of Energy Used for Various Purposes, Selected Regions and

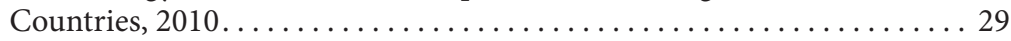

5-1 Energy Input and Output in the U.S. Food System, 2002 . . . . . . . . . . 69

5-2 Civilian Consumption of Transportation Energy in the United States, by Mode and Fuel Type, $2013 \ldots \ldots \ldots \ldots \ldots \ldots \ldots \ldots \ldots \ldots \ldots \ldots \ldots$

7-1 Costs of Mortality from Outdoor Particulate Matter 2.5 $\left(\mathrm{PM}_{2.5}\right)$ Exposure as a Share of GDP (Median Estimates), 15 Largest Carbon Dioxide

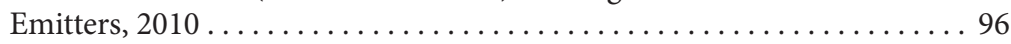

7-2 Small Blocks versus Superblocks .......................... 99

7-3 Income and Job Segregation in the Mexico City Metropolitan Area, 2008 . 102

$7-4$ Three Alternate Futures for Mexico City in $2050 \ldots \ldots \ldots \ldots \ldots \ldots \ldots$

7-5 Urban Footprint Analysis for Mexico City Showing Positive Impacts for the "Vision Scenario" Across a Range of Economic, Social, and Environmental Measures............................. 106

9-1 Cumulative Energy Investment, by Type, Under the International Energy Agency's "450 Scenario," 2014-35 .......................... 143

9-2 Comparison of the Costs and Benefits of Green Schools and Offices ...... 150

11-1 Population and Urban Area in Atlanta and Barcelona, 2014 ........... 178

11-2 Urban Density and Transport-Related Energy Consumption, 1995 ...... 180

11-3 Metro System Openings Worldwide, Cumulative Number and Additions

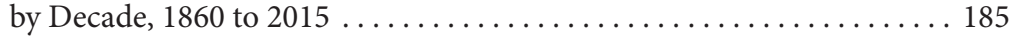

11-4 BRT Systems Worldwide, Cumulative Number and Annual Additions, 1968 to 2015 
12-1 Impact of Low-Carbon Transport Investments on Urban Emissions and Mobility in 2050: Business as Usual versus a "High Shift" Scenario . . . . 196

12-2 Impact of Public- versus Private-Transport Strategies on Modal Share and Transport Emissions in Latin American, Chinese, and Indian Cities

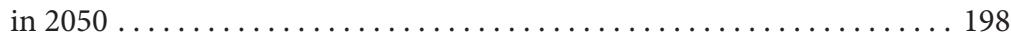

12-3 Share of INDCs Mentioning Various Urban Transport Modes........... 200

12-4 Share of INDCs Mentioning Various Urban Transport Strategies ........ 200

14-1 Waste Management Hierarchy . . . . . . . . . . . . . . . . . . . . . . . . . 246

15-1 Per Capita Income and Meat Availability, Selected Countries, 2011 . . . . . 264

16-1 Distribution of Installed Renewable Power Capacity in Germany, by

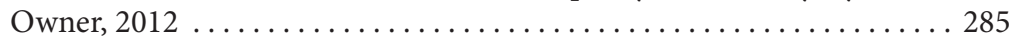

16-2 German Primary Coal Production, $2000-12 \ldots \ldots \ldots \ldots \ldots \ldots \ldots . \ldots . \ldots 286$

17-1 The Three Urban Sub-systems and Their Main Related Biotopes ......... 301

18-1 Most Unequal Cities by Income, Selected Cities in the Developing World,

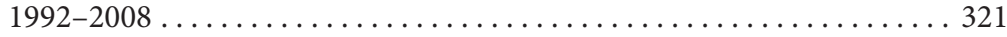




\section{Foreword}

This is a book about hope. A story about possibilities. The sort of story we might entertain while floating in warm water at the edge of the ocean-where life feels more clear, and big ideas rise to the surface. A moment to contemplate what really matters, and to reflect, and dream, and plot. That's what this book is for me.

Clearly, we have a lot to contemplate. Our recent narrative is full of troubling themes, connected and compounding: growing inequality; an increasingly dangerous climate; depleting resources and endangered ecosystems; cultural, ideological, and geopolitical battles intrinsically linked to all of these problems. So complex and daunting are our challenges that it is easy to feel disconnected, powerless.

But this is only part of our story. Reflecting on the state of our ever-changing world requires us to consider not just how things are, but how we would like them to be, and an honest assessment of the course we are on.

This book shares and inspires stories about our potential-about how we can create a more livable and sustainable world-just as much as it reviews our past. It paints a clear picture that we are far from powerless. Across the globe, the narrative of a troubled world is being challenged by stories of leadership, change, and achievement. A growing global movement stands eager to work for the world we want for our children. These stories point to the power of people to craft more thoughtful, sustainable approaches to life on Earth, and our opportunity to write a new narrative of which we can all be proud.

The power of inspired leadership was on full display recently at the United Nations Climate Change Conference in Paris in December 2015. With luck (and work), we may look back on the agreement struck there among nearly 200 nations to tackle the threat of climate change as a defining moment in our history-a bold, collaborative step toward addressing one of the central challenges of our time. The collective leadership of many individuals made that moment possible and will determine our path forward. 
The leadership of cities, in particular, played an enormous role in motivating the global agreement that was struck in Paris. Hundreds of mayors from around the world brought bold local goals and action commitments to the negotiations, setting the bar for leadership and demonstrating a readiness to help negotiating nations meet more-ambitious targets.

Speaking in Paris, United Nations Secretary-General Ban Ki-moon recognized the role of city leaders in helping to "inspire national governments to act more boldly." He noted that cities "have formed a remarkable number of alliances that are accelerating and scaling up climate commitments" and recognized cities for "taking [their] leadership to a new level of cooperation and innovation. ... [They] are the ones who will help turn this global agreement into reality on the ground."

Although the heightened attention to cities during the Paris talks was to some extent a new evolution in the process of international climate negotiations, leaders at the local level have been working to tackle climate change for 25 years. Toronto, Canada, was among the first cities globally to adopt a greenhouse gas reduction target in 1990. The international network of local governments, ICLEI, was founded that same year and launched the Urban $\mathrm{CO}_{2}$ Reduction Project, which 14 international cities joined in 1991.

From Portland to Ankara, Minneapolis to Helsinki, this was the original vanguard of climate action planning-individuals working at the local level who recognized the need and opportunity to tackle a major global challenge through cumulative work across continents. More and more urban leaders joined their thinking, recognizing that all emissions are generated locally, and that many opportunities to reduce them are under local control. They worked together to develop the methods that cities have used ever since to measure greenhouse gas emissions, establish targets, and craft action plans. Their small ideological movement produced a community of practice.

For the first 20 years that cities began to focus on climate, their numbers grew, but the practice evolved slowly. Targets were comfortably set 15-20 years out, with aims to reduce climate pollution by similar percentages. The exercise was largely internal and independent, focusing on cost-effective actions. Political pressure to achieve adopted goals was generally low. City leaders seldom spoke of the need to adapt to climate change, out of fear that this would create an excuse for inaction.

The local movement grew substantially in 2005 when Seattle Mayor Greg Nickels launched the Mayors Climate Protection Agreement, challenging other U.S. mayors to lead the way in reducing emissions in the face of federal 
inaction. More than 1,000 mayors, representing nearly 89 million Americans, joined in making the pledge to take climate action.

Today, momentum is building again, spurred in part by the growing pressures of climate change that cities already are feeling. A new wave of collaboration, innovation, and learning is taking place among leaders at the local level. Cities are listening to the science and establishing more-ambitious goals for reducing emissions. Carbon neutrality. Fossil fuel-free. 100 percent renewable energy. These goals change the equation about prioritizing local action.

Now we recognize that solving the climate challenge will require sweeping societal change. Climate leaders are learning that we must work hard on enabling more-equitable access to resources, security, and the power to make and advocate for lower-carbon choices-as hard as we work on the technical nature of the problem. Rather than avoid talk of climate adaptation, we should seek to enhance local preparedness and resilience while reducing emissions. Local action takes place in the local context, and real progress happens when we solve multiple challenges at once. Cities understand this.

I recently spent five years leading sustainability efforts for the City of Oakland, California. Oakland is a case study of the transformations and leadership emerging in cities on these issues. It is a city eager to take bold action, where the most vocal champions of action on urban sustainability and climate represent diverse communities of color whose work is framed primarily through a social justice lens. Climate action is deeply intertwined with other opportunities to enhance quality of life.

Early in my first year on the job, a colleague from the City of Seattle suggested that we get together with other "sustainability" professionals at the government level to see what we could learn from one other. Sixty-five of us met in Chicago in 2009, sharing stories about issues like energy retrofits, zero waste, and green infrastructure, as well as how we were each making the case for and coordinating this work within our respective bureaucracies. We agreed to talk regularly as a group, and to meet again in a year. The Urban Sustainability Directors Network (USDN) was born-the next wave of collaborative local leadership.

Seven years later, nearly 600 local government professionals participate in USDN. They share common traits as change agents tasked with helping their jurisdictions identify and act on opportunities to enhance sustainability. They are trying new things, learning, sharing, inspiring, pushing, celebrating, and evolving. Peer learning and collaboration has emerged as a powerful force in the network, built on trusted relationships. The dialogue has broadened and 
deepened across 25 streams of more-nuanced group discussions on topics such as climate preparedness, building energy strategies, electric-vehicleinfrastructure planning, and addressing equity in sustainability initiatives.

In cities, the urban sustainability movement is much more than concurrent. It embodies a degree of collaboration that is distinct from many social movements-and that creates space for new leadership and big ideas.

One such idea spurred the 2014 launch of the Carbon Neutral Cities Alliance, a collaboration of international cities committed to achieving ambitious carbon reduction goals of at least 80 percent by 2050 or sooner. These cities are working together to explore how to enact the transformative change necessary to achieve those goals. Some have already proven the value of bold action. From Portland's adoption of an urban growth boundary to concentrate development, to Copenhagen's decision to convert core downtown arteries to bicycle and pedestrian travel, cities in the Alliance are taking some of the boldest action on the planet to address climate change and enhance sustainability.

The stories of this book are inspiring. They offer a narrative of progress and hope. They illustrate that we are not powerless to affect the state of our world. And amid complex topics, they point to simple truths: if we are willing to dream and be bold, if we are willing to work and to work together, if we are willing to embrace and build upon the narrative of leadership that is emerging throughout the world, then a more sustainable future is in our reach.

\section{Garrett Fitzgerald}

Strategic Partnerships Advisor, Urban Sustainability Directors Network 


\section{Foreword}

Cities are synonymous with civilization - in fact, they are the foundation of it. They have always been the major arenas within which high human culture has evolved and flourished, and, since the beginning of the scientific age, they also have been the engines of our expanding knowledge of the planet, its ecosystem, and our place within them. Cities rightly stand as beacons of hope and inspiration to millions and will continue to grow in the coming decades as people on every continent migrate to urban environments seeking better lives.

So it is fitting that cities-where more than half of humanity now lives-are poised on the cutting edge of our attempts to face and master the multiple crises of sustainability that threaten civilization itself. Cities are at a crossroads, confronting historic challenges posed by rising populations, accelerating climate change, increasing inequity, and-all too often —-faltering livability.

Fortunately, as this report-the 33rd volume in the Worldwatch Institute's State of the World series-abundantly illustrates, cities around the planet are stepping forward to lead their citizenry and to support each other in addressing these challenges and in building the sustainable societies of the future. These are not isolated, solitary efforts; vigorous undertakings are plentiful on every continent and within every category of city, from small to vast, from relatively poor to wealthy, and from ancient to sparkling new. Everywhere you look, cities are striving to achieve smaller greenhouse gas footprints, healthier and less alienating communities, more inclusive governance systems, and greater equity and fairness for all their inhabitants.

Cities also have joined forces to share experiences and solutions via peerto-peer networks and to help shape policy at the level of their host nations, as well as internationally. The global organization that I am privileged to chair, the C40 Cities Climate Leadership Group, includes more than 80 of the world's major urban settlements, accounting for over 550 million people and one-quarter of global economic activity. Another organization, ICLEI-Local Governments for Sustainability, is more than 25 years old now and boasts 1,200 
member cities. The Compact of Mayors, a coalition of city leaders focused on climate change and its impacts, includes the leadership of nearly 400 cities representing almost 350 million people. Organizations such as the Urban Sustainability Directors Network and STAR Communities have sprung up with continental-scale portfolios to promote and support sustainability progress at a more local level.

These and other organizations are both creating and deploying a suite of tools and policy options that is rich, adaptable, plentiful, and designed to address the thorniest sustainability problems. Their determined experimentation with these tools clearly shows that sustainability not only is achievable, but, in many cases, also can save money in the long term.

Cities are where most people now live, and will live in the coming decades. Moreover, because they offer access to all the best that human civilization has achieved, cities are where most people want to live. Mayors know that better than anyone. They also know that cities are policy laboratories and have more freedom to innovate than national governments, and that cities are more directly in touch with their citizens and the impacts that sustainability problems - and successes - have on all of us. Building on the new hope created by the breakthrough agreement on climate action achieved in Paris last December, cities stand ready to engage their citizens in building a sustainable future.

State of the World: Can a City Be Sustainable? deeply understands these fundamental facts and assembles an inspiring collection of analyses, stories, examples, and policy options into a vision of a sustainable future that is within our grasp. I urge my fellow mayors and all urbanites to commit themselves to the actions necessary to achieve it.

Eduardo da Costa Paes

Mayor, Rio de Janeiro

Chair, C40 Cities Climate Leadership Group 


\section{Acknowledgments}

If this book were a city, it would be described as diverse and dynamic, maybe even sprawling. But above all, it would be known for its passionate people. Here we offer our deepest thanks to the many people whose hard work helped to bring this book to life.

We are grateful to our dedicated Board of Directors for their tremendous support and leadership: Ed Groark, Robert Charles Friese, John Robbins, Mike Biddle, Tom Crain, James Dehlsen, Edith Eddy, Ping He, Stefan Mueller, David Orr, Scott Schotter, and Richard Swanson, in addition to our Emeritus Directors, Øystein Dahle and Abderrahman Khene.

We also acknowledge, with deep gratitude, the many institutional funders whose support made the Institute's work possible over the past year. La Caixa Banking Foundation deserves early mention for its double role in supporting this volume: as a generous funder and as the matchmaker that introduced us to the excellent researchers at the Autonomous University of Barcelona, whose work appears in these pages. We are grateful for La Caixa's enthusiastic support of our efforts.

In addition, a host of institutions makes work across the entire Institute possible. We are grateful for the support and confidence of the following: 1772 Foundation; The Aiyer Family Fund of Vanguard Charitable; Ray C. Anderson Foundation; Asian Development Bank (ADB); Aspen Business Center Foundation; Caribbean Community (CARICOM); Collins Educational Foundation; Del Mar Global Trust; Ecoworks Foundation; Folk Works Fund of Fidelity Charitable; The Friese Family Fund; Garfield Foundation, Brian and Bina Garfield, Trustees; German Federal Ministry for the Environment, Nature Conservation and Nuclear Safety (BMU) and the International Climate Initiative; German Society for International Cooperation (GIZ) with Meister Consultants Group, Inc.; Goldman Environmental Prize; J. W. Harper Charitable Fund of Schwab Charitable; Hitz Charitable Fund of Schwab Charitable; Steven Leuthold Family Foundation; MOM's Organic Market; National 
Renewable Energy Laboratory (NREL), U.S. Department of Energy; Network for Good; New Horizon Foundation; Paul and Antje Newhagen Foundation of the Silicon Valley Community Foundation; V. Kann Rasmussen Foundation; Robert Rauschenberg Foundation; Renewable Energy Policy Network for the 21st Century (REN21); Serendipity Foundation; Shenandoah Foundation; Sudanshu, Lori \& Anand Family Fund of the Silicon Valley Community Foundation; The Laney Thornton Foundation; Turner Foundation, Inc.; United Nations Foundation; U.S. Agency for International Development (USAID) with Deloitte Consulting LLP; Wallace Global Fund; Johanette Wallerstein Institute; Weeden Foundation Davies Fund; and White Pine Fund of Fidelity Charitable.

Friends of Worldwatch offer vital support of the Institute and provide budget stability that assists our financial planning. Dedicated to creating a sustainable civilization, this core group of readers is critical to achieving the Institute's mission.

For this urban edition of State of the World, the Institute welcomes submissions from a wide range of authors, all of whom contribute atop the many pressures of their own work. We are grateful for insightful contributions from Betsy Agar, Perinaz Bhada-Tata, Peter Calthorpe, Alexander Carius, Andrew Cumbers, Geoffrey Davison, Richard Friend, Sudhir Gota, Pablo Knobel Guelar, Richard Heinberg, Brian Holland, Daniel Hoornweg, Cornie Huizenga, Jim Jarvie, Madhavi Joshi, Martí Boada Juncà, Gregory H. Kats, Anna Larsson, Haibing Ma, Sanskriti Menon, Sean O’Donoghue, Karl Peet, Simone Ariane Pflaum, Ang Wei Ping, Debra Roberts, Kartikeya Sarabhai, Franziska Schreiber, Kristina Solheim, Juan Wei, Peter Wrenfelt, and Roser Maneja Zaragoza. Their expertise and insights add depth and special value to the book. The Honorable Eduardo Paes, Mayor of Rio de Janeiro, Brazil, and Garrett Fitzgerald, Strategic Partnerships Advisor at the Urban Sustainability Directors Network, were kind enough to cap the book with Forewords. Two other big-city mayors and their sustainability staffs-Gregor Robertson of Vancouver, Canada and Robert Doyle of Melbourne, Australia-graciously agreed to contribute perspectives on the challenges and achievements of their respective cities.

We are also fortunate to belong to a generous community of scholars and activists who shared their knowledge with us and introduced us to other experts. Garrett Fitzgerald along with Hilari Varnadore, Executive Director of STAR Communities, deserve special thanks for orienting us to the world of urban research and advocacy. We also benefited from the expertise of many people who either provided critical insights in discussions with us or who 
connected us to the expert authors contributing to this book. They include Adam Beck, Maruxa Cardama, Brenden Carriker, Lena Chan, Felix Creutzig, Ruth DeFries, John Fernandez, Tomasz Filipczuk, Marina Fischer-Kowalski, Colin Hughes, Sadhu Johnston, Christopher Kennedy, Cecile Legrand, Matthew Lynch, Jacob Mason, Laurie Mazur, Amanda McCuaig, Leanne Mitchell, Ranjan Nambiar, Danielle Nierenberg, Alexander Ochs, Cathy Oke, Johanna Partin, Andrea Reimer, Kartikeya Sarabhai, David Sedlak, Karen Seto, Chris Smaje, Michael Small, Doug Smith, Sean Sweeney, Jason Vogel, Kristi Wamstad-Evans, and Sandy Wiggins.

Monika Zimmermann, Deputy Secretary General at ICLEI-Local Governments for Sustainability, connected the project team with a range of "City View" authors and provided critical insights from her work. Preeti ShroffMehta, Worldwatch India Program Senior Fellow, was an energetic intermediary, strengthening our budding collaboration with the Centre for Environment Education (CEE) in Ahmedabad. We benefited from early discussions with CEE Director Kartikeya Sarabhai, who also contributed to the book.

We are particularly indebted to Worldwatch interns Shashank Gouri and Kristina Solheim for their diligence in digging out obscure information and checking facts for the book. Their thorough and cheerful approach to research made working with them a pleasure.

State of the World is ably edited by Lisa Mastny, who quickly and skillfully sharpens authors' writing and harmonizes their diverse styles. Lisa also manages the production process as a key point person between authors and designer. We greatly value her skill in ensuring that the book is in good shape and delivered on time. Independent designer Lyle Rosbotham showcases the written word through exceptional design, creating elegant graphics and a beautiful layout. And Kate Mertes faithfully and quickly creates an accurate index that makes the book highly accessible.

Once the book is produced, Worldwatch Marketing and Communications Director Gaelle Gourmelon disseminates its messages far beyond our Washington offices and advises staff on the effective use of new communication tools. Director of Finance and Administration Barbara Fallin manages the many details of Institute operations with great efficiency and dispatch. And Director of Institutional Relations Mary Redfern keeps our staff apprised of funding opportunities and manages our relationships with foundations, ever on the lookout for new opportunities for Worldwatch.

We continue to benefit from a fruitful partnership with our publisher, Island Press, which is globally recognized as a first-rate sustainability publishing 
house. We appreciate the professional and collegial efforts of Emily Turner Davis, Maureen Gately, Jaime Jennings, Julie Marshall, David Miller, Sharis Simonian, and the rest of the IP team.

Worldwatch's publishing partners extend our global reach through their work in translation, outreach, and distribution of the book. We give special thanks to Worldwatch Brasil; Paper Tiger Publishing House (Bulgaria); China Social Sciences Press; Worldwatch Institute Europe (Denmark); Organization Earth (Greece); Earth Day Foundation (Hungary); Centre for Environment Education (India); WWF-Italia and Edizioni Ambiente (Italy); Worldwatch Japan; Korea Green Foundation Doyosae (South Korea); FUHEM Ecosocial and Icaria Editorial (Spain); Taiwan Watch Institute; and Turkiye Erozyonla Mucadele, Agaclandima ve Dogal Varliklari Koruma Vakfi (TEMA), and Kultur Yayinlari IsTurk Limited Sirketi (Turkey).

We are particularly appreciative of the special efforts made by individuals to advance our work overseas, typically on a volunteer basis. Gianfranco Bologna is the force behind the Italian edition of State of the World. We have been lucky to enjoy his gracious hospitality on our visits there for more than two decades. Eduardo Athayde is an indefatigable promoter of Worldwatch in Brazil. Meanwhile, Soki Oda labors tirelessly over Japanese translations of the volume. We are grateful for his careful review of our work.

Finally, we tip our hats to the many cities and urban-interest organizations that have shown courageous leadership on climate issues over the past decade and more. In an era when many national governments would not embrace their climate responsibilities, cities have pointed the way forward. Their example and their advocacy helped make possible the 2015 climate agreement in Paris, which keeps alive the hope of a stabilized climate for our world's people. For this gift, we are deeply grateful.

Gary Gardner, Tom Prugh, and Michael Renner

Project Directors

Worldwatch Institute

1400 16th Street, NW, Suite 430

Washington, DC 20036

worldwatch@worldwatch.org

www.worldwatch.org

www.canacitybesustainable.org 


\section{World's Cities at a Glance}

\section{Gary Gardner}

Cities have emerged as the dominant form of human settlement, and they are major economic and environmental actors. The data that follow give a sense of cities as a global phenomenon and of their place in human civilization in the twenty-first century.

\section{People}

Since 1950, the global urban population has increased by roughly a factor of five, from 0.7 billion in 1950 to 3.9 billion in 2014. It is expected to increase by another 60 percent by 2050 , when 6.3 billion people are projected to live in urban settlements. ${ }^{1}$

As of 2009, more than one-half of the world's people live in cities (see Figure, page xxviii), and the urbanization trend is continuing. More than 90 percent of urban growth is happening in developing countries, although not all developing regions are majority-urban yet. By 2040, all world regions, including Africa, will be majority-urban. ${ }^{2}$

Urban growth rates are stable or slow in highly urbanized regions such as Europe, Latin America, and Oceania, but Asia and Africa are urbanizing quickly. The fastest urban growth is in Africa, where growth rates in some countries exceed 5 percent per year. Europe has the world's lowest urban growth, and in some Eastern European countries, rates are actually negative. ${ }^{3}$

Over the past 65 years, the number of "megacities"-cities with 10 million or more inhabitants-has grown more than 14-fold, from 2 in 1950 to 29 in 2015. (See Map, pages $\mathrm{xxx}$-xxxi.) By 2030, the world is projected to have 41

Gary Gardner is Director of Publications at the Worldwatch Institute. 


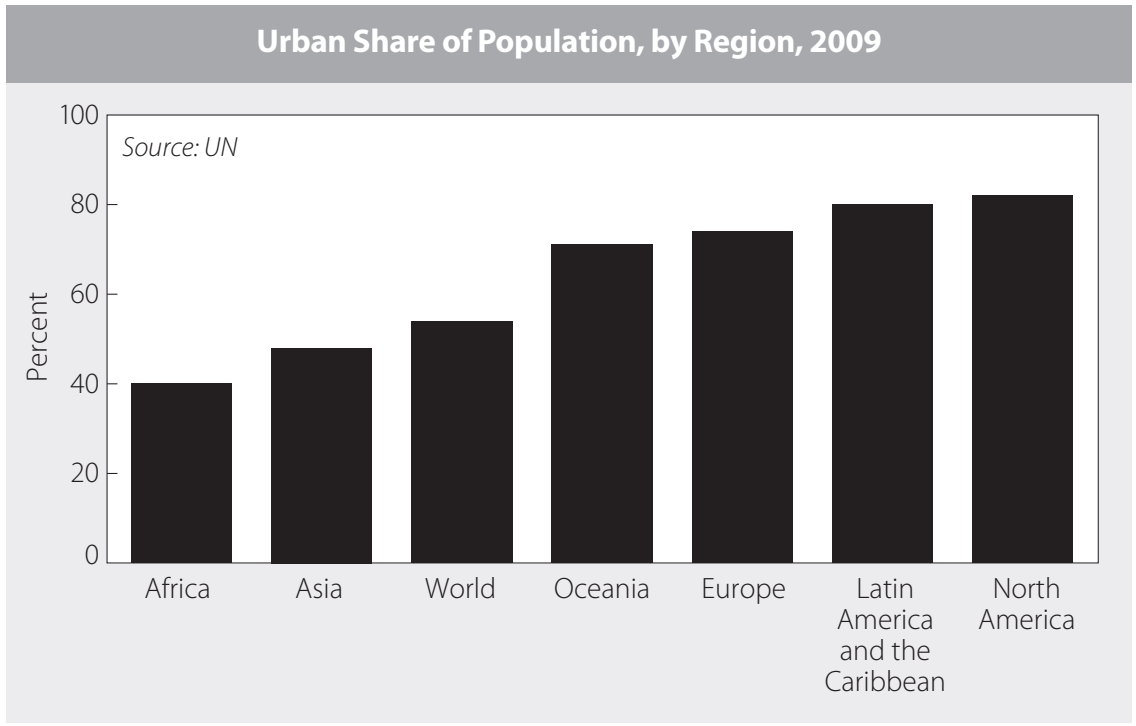

megacities. But nearly half of all urbanites live in cities of fewer than 500,000 people. The number of cities with more than 500,000 people has grown nearly sixfold since 1950 , from 304 to $1,729 .{ }^{4}$

\section{The Built Environment}

The built-up land of cities covers 1-3 percent of global land area, but this could grow to $4-5$ percent by 2050 as urban areas expand outward, primarily into prime agricultural land. ${ }^{5}$

Cities are becoming less dense: for decades, across all world regions, the urban land area has expanded faster than the population. If average densities continue to decline, the built-up areas of developing-country cities will increase threefold by 2030 while their populations double. (See Table.) Industrializedcountry cities are projected to expand 150 percent while their populations increase by 20 percent. An estimated 60 percent of the built environment needed to accommodate the earth's urban population by 2050 is not yet built. ${ }^{6}$

Household sizes are falling in many countries, which is contributing to an increase in the number of dwellings and the resources required to build them. By 2025, the growth in the number of households is projected to be 2.3 times the population growth rate in the world's top cities. The construction industry 
Expected Increase in Area and Population of Cities by 2030

Projected Increase by 2030 in

Built-up Area

Population

\begin{tabular}{lcc}
\hline & percent \\
\hline Developing-country cities & 200 & 100 \\
Industrialized-country cities & 150 & 20 \\
\hline
\end{tabular}

Source: See endnote 6.

is a major consumer of resources, including 40 percent of all water, 70 percent of timber products, and 45 percent of energy. ${ }^{7}$

By one estimate, cities will need to double their annual investment in physical capital to $\$ 20$ trillion annually by 2025 , most of this in emerging economies. ${ }^{8}$

\section{Urban Economies}

Cities are economic engines: some 80 percent of the global gross domestic product (GDP) is produced in cities, and 60 percent is produced in the 600 most-productive cities, where one-fifth of the world's population now lives. Urban economic activity accounts for up to 55 percent of gross national product (GNP) in low-income countries, 73 percent in middle-income countries, and 85 percent in high-income countries. Cities generate a disproportionate amount of revenue for governments. ${ }^{9}$

Urban areas account for a large share of global consumption, including 60-80 percent of energy consumption and more than 75 percent of natural resource consumption. They account for 75 percent of the world's carbon emissions. ${ }^{10}$

Economic power is increasing in cities in emerging economies. By 2025, many of the cities that currently are in the world's wealthiest countries will not even make the list of the 600 richest cities (in terms of GDP) as new cities-in China, the Democratic Republic of the Congo, Nigeria, Indonesia, Pakistan, and India, among other countries-displace them. ${ }^{11}$

An estimated 1 billion people will become part of the global "consuming class" by 2025. They are expected to inject $\$ 20$ trillion of additional spending annually into the global economy. ${ }^{12}$ 

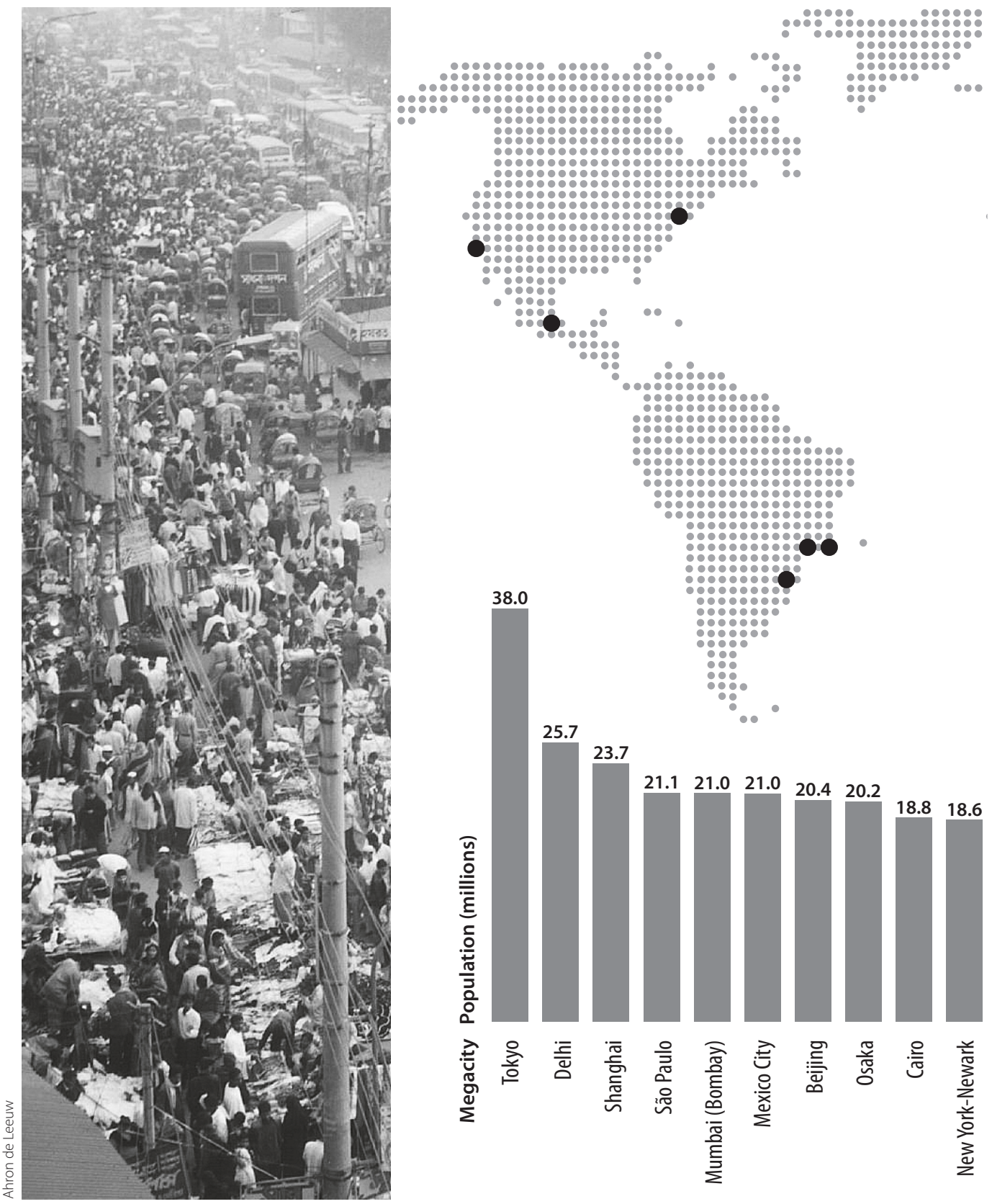

\section{7}

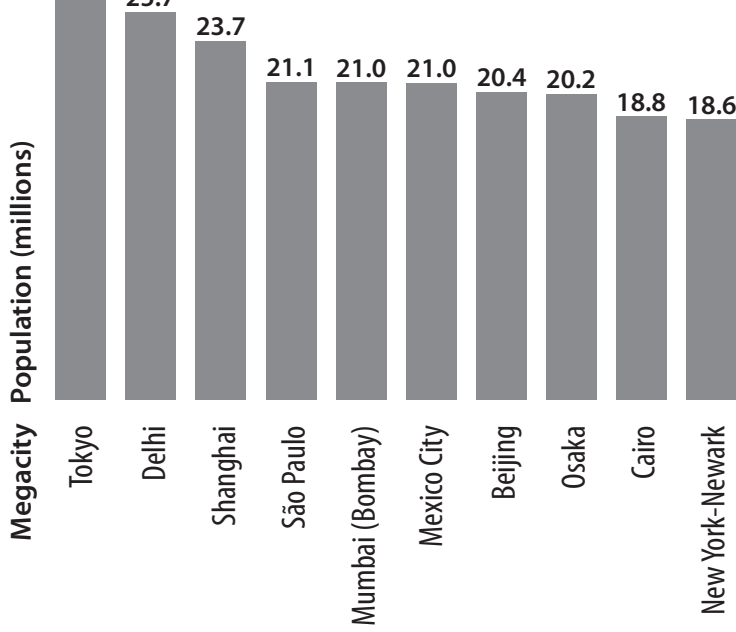

Dhaka, Bangladesh, 17.6 million people. 


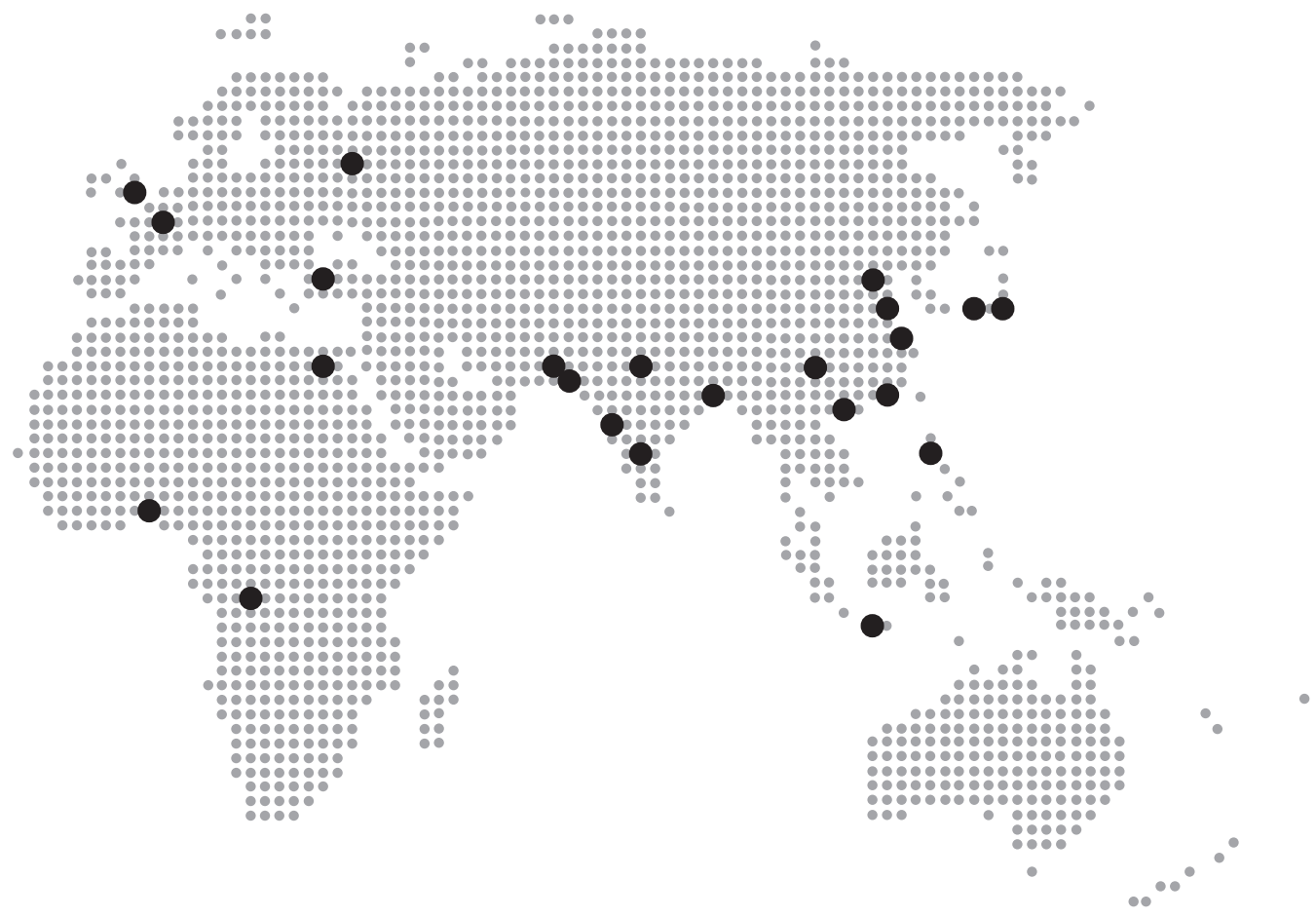

- Megacity

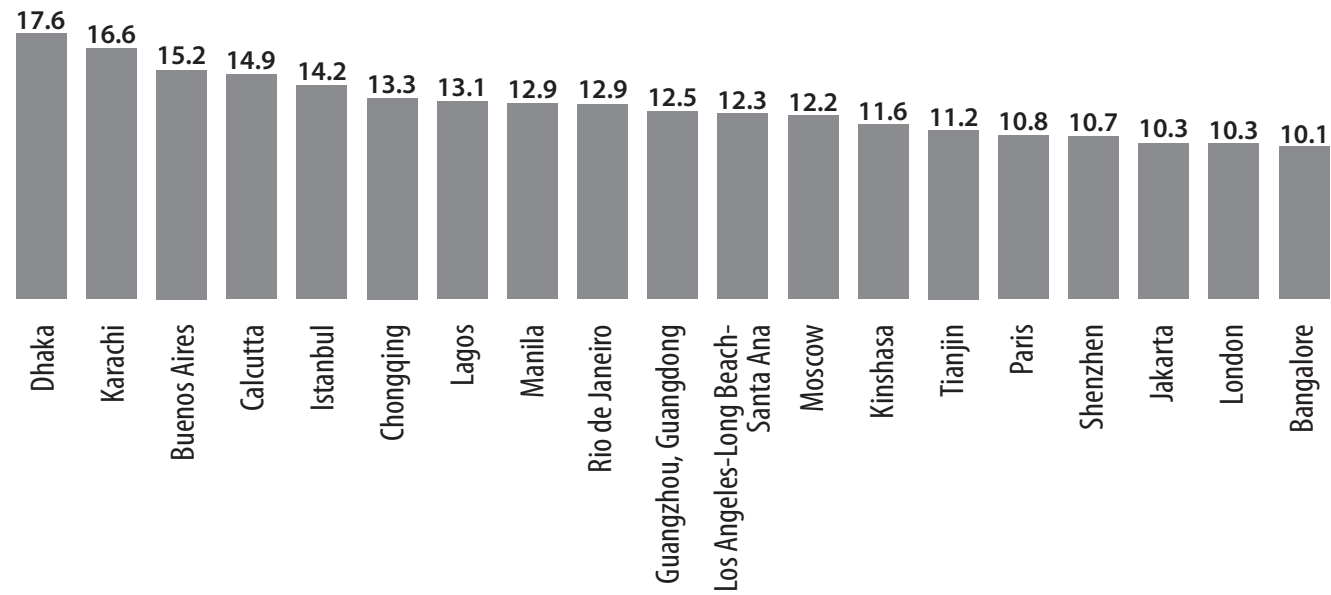


Consumption in the lowest- and highest-consuming megacities differs by a factor of 28 in energy per capita, a factor of 23 in water per capita, a factor of 19 in waste production per capita, a factor of 35 in total steel consumption, and a factor of 6 in total cement consumption. Ten percent of the urban population of developing countries lacks access to electricity, and 18 percent uses wood, dung, or charcoal for cooking. The figures are much higher for urban populations in the least-developed countries. ${ }^{13}$

\section{Poverty, Sanitation, and Health}

Although cities are economic engines, they also can be centers of poverty. Approximately 1 in 7 people in urban areas lives in poverty, mostly in informal settlements of the developing world. An estimated 863 million urban residents were living in slum conditions in 2012, up from 650 million in 1990. Yet the overall share of urban populations living in slums fell over this period, from 46 percent to 33 percent. $^{14}$

Less than 35 percent of cities in developing countries treat their wastewater. About 500 million urban dwellers worldwide share sanitation facilities with other households. More than 170 million urban residents lack access to even the simplest latrine and have no choice but to eliminate their waste in the open. ${ }^{15}$

Some 1.5 billion urban dwellers face levels of outdoor air pollution that exceed the maximum recommended limits. In 2012, outdoor air pollution killed an estimated 7 million people, representing 1 in 8 deaths globally and making air pollution the largest single environmental health risk. Meanwhile, indoor air pollution (from the burning of solid fuels for cooking) killed an estimated 4 million people in $2014 .{ }^{16}$ 